\title{
ERRATA VOLUME 73 EDIÇÃO 1
}

Expressão de ciclina D1 e presença de metástase cervical de carcinoma epidermóide de boca

Cyclin D1 expression and cervical metastases in squamous cell carcinoma of the mouth

Gerson Schulz Maabs • Denise Cantarelli Machado • Emilio Antonio Jeckel-Neto • Vinicius Schenk Michaelses

Correção do Nome do Autor

Vinicius Schenk Michaelsen. 